\title{
EFEKTIVITAS HCI DAN NaOH SEBAGAI PRETREATMENT KOLAGEN KULIT KAKI AYAM
}

\author{
Nur Rif'atul Chasanah ${ }^{1}$, Yuniarti Dewi Rahmawati ${ }^{2 *}$, Muhammad Hasdar ${ }^{3}$ \\ ${ }^{1,3}$ Program Studi Ilmu dan Teknologi Pangan, Fakultas Sains dan Teknologi, Universitas Muhadi \\ Setiabudi, Indonesia \\ ${ }^{2}$ Program Studi S1-Gizi, Fakultas Ilmu Kesehatan, Universitas Muhadi Setiabudi, Indonesia \\ *e-mail: ${ }^{1}$ yuniartidewi.rahmawati@gmail.com
}

\begin{abstract}
ABSTRAK
Kolagen merupakan protein alami yang terdapat pada hewan, digunakan secara luas pada industri pangan sebagai bahan tambahan. Kulit kaki ayam adalah bagian yang dianggap sebagai hasil samping yang mempunyai nilai fungsional dan ekonomis yang rendah Indonesia masih mengandalkan impor kolagen untuk memenuhi kebutuhan industri pangan sehingga diperlukan alternatif bahan dan proses produksi kolagen. Penelitian ini bertujuan mencari formula untuk mendapatkan kualitas kolagen kulit kaki ayam terbaik dari proses pretreatment $\mathrm{HCl}$ dan $\mathrm{NaOH}$. Ekstraksi kolagen dilakukan dengan pretreatment $\mathrm{HCl}$ dan $\mathrm{NaOH}$ dengan konsentrasi $2 \%$ dan $4 \%$. Berdasarkan hasil daftar sidik raga, rerata rendemen tertinggi yaitu pada pretreament $\mathrm{NaOH} 4 \%$ dengan persentasi $59.67 \pm 12.70$ sedangkan rerata rendemen terendah pada pretreament $\mathrm{NaOH} 2 \%$ dengan persentasi $37.67 \pm 4.51$. Hasil daftar sidik ragam dengan $\mathrm{pH}$ didapatkan pretreatment $\mathrm{NaOh} 4 \%$ memiliki rerata $\mathrm{pH}$ tertinggi yaitu $12.03 \pm 0.82$ dan $\mathrm{HCl} 4 \%$ memiliki rerata $\mathrm{pH}$ terendah yaitu $2.7 \pm 0.45$. Berdasarkan hasil daftar sidik ragam rerata berat kasar kolagen tertinggi pada pretreatment $\mathrm{NaOH} 4 \%$ yaitu $48.93 \pm 0.69$ dan rerata berat kasar kolagen terendah pada pretreatment $\mathrm{HCl} 2 \%$ yaitu $14.78 \pm 0.38$. Formula yang tepat untuk memproduksi kolagen kulit kaki ayam adalah menggunakan pretreament $\mathrm{NaOH} 4 \%$ dan kualitas kolagen terbaik dihasilkan oleh pretreament $\mathrm{NaOH} 4 \%$.
\end{abstract}

Kata kunci: Kolagen, Kulit kaki ayam, $\mathrm{NaOH}, \mathrm{HCl}$

\begin{abstract}
Collagen is a natural protein found in animals, it is widely used in the food industry as an additive. Chicken feet skin is a part that is considered as a by-product that has low functional and economic value. Indonesia still relies on imported collagen to meet the needs of the food industry so that alternative materials and collagen production processes are needed. This study aims to find a formula to get the best quality chicken leg collagen from the $\mathrm{HCl}$ and $\mathrm{NaOH}$ pretreatment processes. Collagen extraction was carried out by pretreatment with $\mathrm{HCl}$ and $\mathrm{NaOH}$ with concentrations of $2 \%$ and $4 \%$. Based on the results of the physical examination, the highest average yield was in the 4\% NaOH pretreat with a percentage of $59.67 \pm 12.70$ while the lowest average yield was in the $2 \% \mathrm{NaOH}$ pretreat with a percentage of $37.67 \pm 4.51$. The results of the list of variances with $\mathrm{pH}$ showed that $4 \% \mathrm{NaOh}$ pretreatment had the highest average pH of $12.03 \pm$ 0.82 and $4 \% \mathrm{HCl}$ had the lowest average $\mathrm{pH}$ of $2.7 \pm 0.45$. Based on the results of the variance list, the highest average crude weight of collagen in $4 \% \mathrm{NaOH}$ pretreatment was $48.93 \pm 0.69$ and the lowest average crude weight of collagen was $14.78 \pm 0.38$ in $\mathrm{HCl}$ pretreatment. The right formula for producing chicken leg skin collagen is to use $4 \% \mathrm{NaOH}$ pretreatment and the best quality collagen is produced by $4 \%$ $\mathrm{NaOH}$ pretreatment.
\end{abstract}

Keywords: Collagen, Chicken leg skin, $\mathrm{NaOH}, \mathrm{HCl}$

\section{PENDAHULUAN}

Kolagen adalah satu jenis protein yang diperoleh dari kulit, tulang, dan organ hewan mamalia, reptil atau ungags, terbentuk dari tiga rantai polipeptida, tersusun sebagai jaringan fiber yang kuat namun lentur, menjadikannya memiliki banyak kegunaan. Kolagen dapat digunakan di industri pangan dan kesehatan. Dalam industri pangan kolagen biasanya digunakan untuk edible film dan bahan tambahan pangan, sedangkan untuk kesehatan digunakan untuk drug carrier dan peningkat ketahanan tubuh. 
Protein kolagen merupakan salah satu jenis protein jaringan ikat yang mempunyai struktur triple heliks yang sangat kuat dan membentuk pluntiran yang menjadikan jaringan ikat kolagen dapat bersifat lentur dan mampu mengerut dan meregang yang sangat bermanfaat dalam aplikasinya dalam dunia pangan dan kesehatan. Isolasi kolagen merupakan cara yang digunakan untuk mendapatkan kolagen murni yang terdapat di dalam kulit maupun tulang yang ada di dalam tubuh. Cara untuk mengisolasi kolagen dapat dilakukan dengan cara mengekstraksi kulit atau tulang ke dalam pelarut atau solven. Ekstraksi merupakan metode pemisahan suatu komponen dari campurannya dengan menggunakan solven sebagai pemisah. Faktor-faktor yang mempengaruhi proses ekstraksi diantaranya jenis pelarut, suhu, ukuran bahan dan waktu inkubasi [1]. Proses ekstraksi protein pada dasarnya dipengaruhi oleh $\mathrm{pH}$, suhu, jenis dan konsentrasi pelarut serta lama ekstraksi [2].

Penelitian tentang kolagen telah dilakukan oleh banyak peneliti yang diperoleh dari berbagai macam sumber antara lain kulit ikan nila [3], tulang ikan tengiri [4], kulit ikan kila hitam (Oreochromis niloticus) [5] dan tulang kaki ayam (Gallus gallus bankiva) [6].

Produk turunan dari kolagen adalah gelatin [1]. Bahan yang digunakan untuk menghidrolisis kolagen kulit agar dihasilkan gelatin terdapat dua larutan yaitu asam dan basa. Secara umum gelatin terdiri dari dua tipe yaitu tipe A dan tipe B yang didasarkan pada metode pretreatmentnya. Tipe A biasanya menggunakan pretreatment larutan asam sedangkan tipe B menggunakan pretreatment larutan alkali atau basa [7]. Bahan baku gelatin berperan dalam penentuan jenis proses produksi gelatin. Proses gelatin tipe A dapat digunakan untuk memproses semua bahan baku gelatin terutama yang kolagennya muda atau lunak, seperti tulang dan kulit hewan kecil (skin), dan serta kulit ikan. Sedangkan proses produksi gelatin tipe B cocok digunakan untuk memproses bahan baku yang struktur triple helix kolagennya lebih tua, padat, dengan ikatan silang lebih kompleks yaitu berupa tulang dan kulit hewan besar [1].

Kolagen yang beredar di Indonesia umumnya barang impor dari Perancis, Jepang, India, Brazil, Jerman, China, Argentina dan Australia [3]. Impor kolagen menunjukkan bahwa kebutuhan di dalam negeri sangatlah tinggi sehingga diperlukan alternative lain dalam memproduksi kolagen. Alternative lain untuk menghasilkan kolagen dengan kualitas yang lebih baik adalah menggunakan kulit kaki ayam sebagai bahan baku memprodukdi kolagen.

Kulit kaki ayam adalah bagian yang selama ini dianggap sebagai hasil samping yang mempunyai nilai fungsional dan ekonomis yang rendah padahal mengandung kolagen sebanyak $30 \%$ dan memiliki nilai fungsional diantaranya dalam aktivitas hemostatic, biodegradability dan biocompatibility [2]. Kulit kaki ayam banyak terdapat di tempat pemotongan hewan, pasar tradisional, maupun supermarket. Komponen kaki ayam (sank) terdiri atas kulit, tulang, otot dan kolagen [8]. Komponen jaringan yang mengandung kolagen terbanyak terdapat pada kulit yaitu mencapai $89 \%$ kemudian tendon $85 \%$ dan tulang $24 \%$ [1].

Produksi ceker ayam di Indonesia diperkirakan mencapai 1,9 juta pasang potongan atau seberat 42,75 ribu ton ceker ayam per tahun. Nilai tersebut dihitung berdasarkan produksi daging ayam ras sebesar 1.500,47 ribu ton dikalikan konversi karkas $1,33 \mathrm{~kg}$ per ekor ayam serta konversi berat 45 gram/pasang ceker ayam [2]. Berdasarkan data tersebut maka ekstraksi kolagen dari kulit kaki ayam merupakan salah satu upaya untuk meningkatkan nilai ekonomis hasil samping dari produk ayam. Bahan yang digunakan sebagai pelarut yaitu asam dan basa.

\section{BAHAN DAN METODE}

Penelitian dilaksanakan di Laboratorium Kimia Universitas Muhadi Setiabudi. Alat yang digunakan pada penelitian ini adalah pisau, wadah baskom, panci, kompor listrik, gelas ukur, gelas beker, pengaduk, thermometer, timbangan analiti, sendok kecil, freezer, mixer, spatula, dan saringan. Bahan yang digunakan pada penelitian ini adalah ceker ayam atau kaki ayam, $\mathrm{HCl} 2 \%$ dan $4 \%, \mathrm{NaOH} 2 \%$ dan $4 \%$, aquadest dan alkohol. Rancangan penelitian ini adalah rancangan acak lengkap pola faktorial diamana jenis pretreatmen adalah faktor pertama dan konsentrasi pretreatmen adalah faktor kedua. Tahapan penelitian adalah ekstraksi kolagen kaki ayam membandingkan kolagen kulit kaki ayam yang dihasilkan $\mathrm{HCl} 2 \%$ dan 4\% dan kolagen kulit kaki 
ayam yang dihasilkan $\mathrm{NaOH} 2 \%$ dan $4 \%$ yang kemudian dilakukan pengujian menggunakan uji ANOVA dengan signifikansi $95 \%$.

Tahapan penelitian meliputi: (1) Persiapan bahan baku, Kulit kaki ayam yang telah didapat, dicuci terlebih dahulu dengan air bersih, kemudian ditiriskan. Selanjutnya kulit yang sudah terpisah dengan tulangnya dipotong kecil-kecil berukuran 1-2 cm. (2) Pre-treatmen, Kulit kaki ayam selanjutkan direndam dengan larutan $\mathrm{HCl}$ dan $\mathrm{NaOH}$ menggunakan erlenmeyer sesuai perlakuan selama 24 jam. Setelah direndam kemudian disaring dengan kain saring atau kertas saring. Selanjutnya kulit kaki ayam hasil perendaman dimasukkan kembali dalam erlenmeyer untuk proses selanjutnya.(3) Ekstraksi, Ekstraksi dilakukan menggunakan waterbath pada suhu 50-60oC selama 3 jam. Perbandingan kulit kaki ayam dan air untuk ekstrasi adalah $1: 3$. (4) Hasil Ekstraksi, Ekstrak diperoleh kemudian disaring dan diukur volumenya, ekstrak ditempatkan dalam wadah sampel dan didinginkan dalam wadah sampel, dapat didinginkan atau disimpan dalam lemari es.(5) Parameter, Parameter penelitian ini yaitu kualitas kolagen kulit kaku ayam dilihat dari rendemen, $\mathrm{pH}$ dan dan serat kasarnya.

\section{Rendemen}

\section{HASIL DAN PEMBAHASAN}

Rendemen merupakan hasil akhir yang diperoleh dari ekstraksi kolagen yang menunjukkan efektif atau tidaknya metode yang digunakan. Nilai rendemen penting untuk diketahui, karena berguna untuk perencanaan produksi, penggunaan peralatan produksi, kapasitas produksi, kebutuhan bahan baku, perhitungan biaya produksi/ tekno ekonomi, disamping itu juga dapat digunakan untuk mengetahui efisiensi proses dan lainnya [1]. Rendemen pada penelitian ini disajikan pada tabel 1 .

Tabel 1. Pengaruh pretreatment terhadap rendemen

\begin{tabular}{ccccc}
\hline & & \multirow{2}{*}{ Ulangan } & \multicolumn{2}{c}{ Faktor B (Konsentrasi) } \\
\cline { 3 - 5 } & & 1 & $2 \%$ & $4 \%$ \\
& \multirow{2}{*}{$\mathrm{HCl}$} & 2 & 50 & 48 \\
& & 3 & 42 & 62 \\
Faktor A & Rata-rata & 49 & 56 \\
\cline { 2 - 5 } (Pretreatment) & 1 & $47 \pm 4.36$ & $55.3 \pm 7.02$ \\
\cline { 2 - 5 } & \multirow{2}{*}{$\mathrm{NaOH}$} & 2 & 38 & 67 \\
& & 3 & 33 & 67 \\
\cline { 2 - 5 } & & 42 & $59.67 \pm 12.70$ \\
\hline
\end{tabular}

Data hasil statistik pengujian hipotesis dapat dilihat pada tabel 2 dan tabel 3.

Tabel 2. Levene's Test of Equality of Error Variances dengan rendemen sebagai variabel dependen.

\begin{tabular}{cccc}
\hline F & df1 & df2 & Sig. \\
\hline 2.920 & 3 & 8 & .100 \\
\hline
\end{tabular}

Keterangan : Pengujian hipotesis nol berdasarkan varian kesalahan pada variable dependen pada semua kelompok

Dari hasil daftar sidik ragam pada tabel 2 menujukkan bahwa nilai (Signifikansi) Sig. 0,100 di mana $>0,05$ sehingga bisa dikatakan varian antar group berbeda secara signifikan.

Tabel 3. Tests of Between-Subjects Effects dengan rendemen sebagai variabel dependen

\begin{tabular}{ccccccc}
\hline Source & $\begin{array}{c}\text { Type III Sum } \\
\text { of Squares }\end{array}$ & df & Mean Square & F & Sig. \\
\hline
\end{tabular}




\begin{tabular}{lccccc}
\hline Corrected Model & $848.917^{\mathrm{a}}$ & 3 & 282.972 & 4.528 & .039 \\
Intercept & 29900.083 & 1 & 29900.083 & 478.401 & .000 \\
Faktor_A & 18.750 & 1 & 18.750 & .300 & .599 \\
Faktor_B & 690.083 & 1 & 690.083 & 11.041 & .010 \\
Faktor_A* Faktor_B & 140.083 & 1 & 140.083 & 2.241 & .173 \\
Error & 500.000 & 8 & 62.500 & & \\
Total & 31249.000 & 12 & & & \\
Corrected Total & 1348.917 & 11 & & & \\
\hline
\end{tabular}

Dari tabel 2 dan 3 di atas, kita mendapatkan nilai-nilai penting yang bisa disimpulkan sebagai berikut:

\section{Corrected Model (Model yang dikoreksi)}

Pengaruh Semua Variabel independen (faktor A, faktor B dan Interaksi faktor A dengan faktor B atau "faktor A * faktor B") secara bersama-sama terhadap variabel dependen (rendemen). Apabila Signifikansi (Sig.) < 0,05 (Alfa) maka model tersebut dikatakan signifikan atau dengan kata lain bahwa data diatas yang menunjukkan nilai 0,039 berarti memiliki model valid.

\section{Intercept (Penyadapan)}

Nilai perubahan variabel dependen tanpa perlu dipengaruhi keberadaan variabel independen, artinya tanpa ada pengaruh variabel independen, variabel dependen dapat berubah nilainya. Apabila Signifikansi (Sig.) $<0,05$ (Alfa) maka dapat dikatakan intercept signifikan. Data di atas menunjukkan nilai 0,000 berarti intercept signifikan.

\section{Faktor A}

Pengaruh faktor A terhadap hasil rendemen dapat dikatakan signifikan bila Signifikansi (Sig.) < 0,05. Data di atas menunjukkan nilai 0,599 sehingga faktor A tidak memberikan berpengaruh signifikan pada hasil rendemen.

\section{Faktor B}

Pengaruh Faktor B terhadap hasil rendemen dapat dikatakan signifikan bila Signifikansi (Sig.) <0,05 (Alfa). Data di atas menunjukkan nilai 0,010 sehingga factor B memberikan pengaruh yang signifikan terhadap hasil rendemen.

\section{Faktor A* Faktor B:}

Pengaruh faktor A* faktor B terhadap hasil rendemen bernilai signifikan (Sig.) apabila nilai signifikansi $<0,05$ (Alfa). Data di atas menunjukkan nilai 0,173 berarti faktor A * faktor B tidak berpengaruh signifikan.

Jenis pretreatment memberikan pengaruh yang berbeda secara sinifikan terhadap rendemen kolagen kulit kaki ayam (tabel 2). Pretreatment $\mathrm{NaOH} 4 \%$ memberikan hasil rendemen tertinggi dibandingkan pretreatment $\mathrm{HCl}$. Rerata rendemen kolagen $\mathrm{NaOH} 4 \%$ adalah $59.67 \pm 12.70$ lebih tinggi dibandingkan rerata rendemen $\mathrm{HCl} 4 \%$ yaitu $55.3 \pm 7.02$. Tingginya rendemen kolagen pretreament menunjukkan bahwa pretreatment $\mathrm{NaOH} 4 \%$ mampu menghasilkan rendemen lebih tinggi dibandingkan dengan pretreatment yang lain. Hal ini juga menunjukkan bahwa pretreatment $\mathrm{NaOH} 4 \%$ lebih efektif untuk menghasilkan kolagen.

Hasil penelitian ini sejalan dengan hasil penelitian Indrawan et al., (2016) melaporkan bahwa untuk mendapatkan hasil rendemen tertinggi dengan waktu yang relatif singkat atau lebih sedikit adalah dengan larutan basa $\mathrm{NaOH} 2 \%$. Pada penelitian Indrawan et al., (2016) untuk penggunaan $\mathrm{NaOH} 2 \%$ diperoleh waktu perendaman optimum pada lama perendaman 1 hari dengan rendemen gelatin tertinggi yaitu $10.48 \%$ [9].

Penelitian Wijaya et al., (2015) juga menyebutkan bahwa pelarut terbaik adalah $\mathrm{NaOH}$. $\mathrm{NaOH}$ terbukti mampu memaksimalkan degreasing, yaitu proses mengikis lemak pada bahan baku [10]. Perbedaan konsentrasi berpengaruh terhadap perolehan kolagen. Semakin tinggi konsentrasi pretreatment maka jumlah rendemen juga akan meningkat, namun setelah mencapai konsentrasi maksimal, akan terjadi proses hidrolisis berkelanjutan yang berakibat terpotongnya 
fraksi kolagen menjadi fraksi-fraksi protein dengan bobot molekul lebih rendah daripada gelatin sehingga menurunkan hasil rendemen [9].

pH

Nilai $\mathrm{pH}$ dihitung dengan mengukur tiap sampel menggunakan $\mathrm{pH}$ meter. Pada tabel 4 ditampilkan pengaruh pretreatment terhadap $\mathrm{pH}$.

Tabel 4. Pengaruh pretreatment terhadap $\mathrm{pH}$

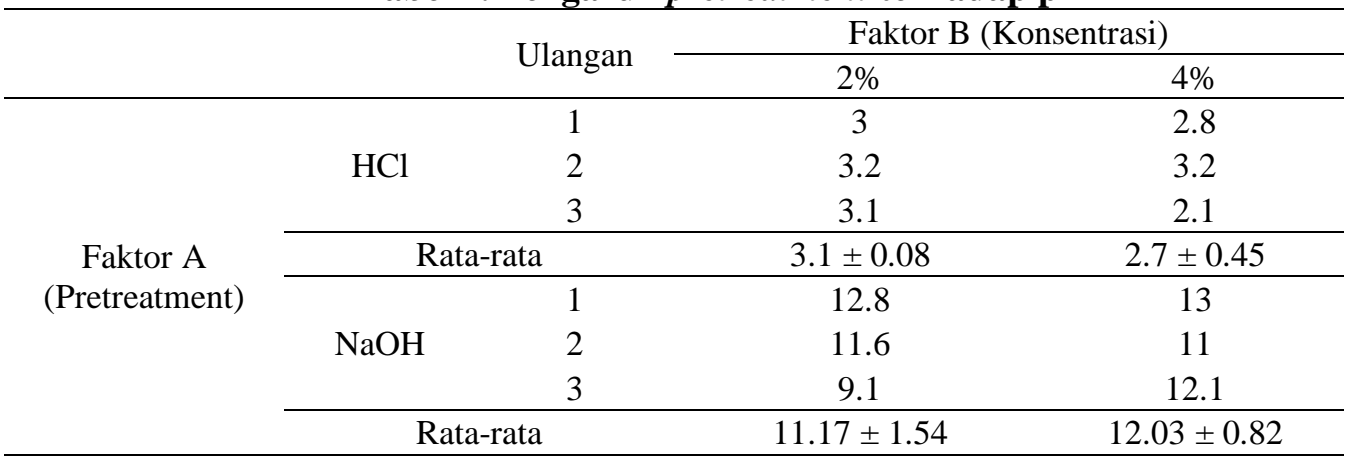

Tabel 5. Levene's Test of Equality of Error Variances dengan $\mathrm{pH}$ sebagai variable dependen.

\begin{tabular}{cccc}
\hline F & df1 & df2 & Sig. \\
\hline 3.453 & 3 & 8 & .072 \\
\hline
\end{tabular}

Keterangan : Pengujian hipotesis nol berdasarkan varian kesalahan pada variable dependen pada semua kelompok

Dari hasil daftar sidik ragam pada tabel 5 menunjukkan bahwa nilai signifikansi 0,072. Sehingga dapat dikatakan bahwa varian antar grup berbeda secara signifikan dikarekan nilai signifikansi lebih dari 0,05 .

Tabel 6. Tests of Between-Subjects Effects dengan pH sebagai variabel dependen

\begin{tabular}{lrrrrr}
\hline \multicolumn{1}{c}{ Source } & $\begin{array}{c}\text { Type III Sum } \\
\text { of Squares }\end{array}$ & df & Mean Square & \multicolumn{1}{c}{ F } & \multicolumn{1}{c}{ Sig. } \\
\hline Corrected Model & $228.437^{\mathrm{a}}$ & 3 & 76.146 & 62.329 & .000 \\
Intercept & 630.750 & 1 & 630.750 & 516.303 & .000 \\
Faktor_B & .163 & 1 & .163 & .134 & .724 \\
Faktor_A & 227.070 & 1 & 227.070 & 185.869 & .000 \\
Faktor_B * Faktor_A & 1.203 & 1 & 1.203 & .985 & .350 \\
Error & 9.773 & 8 & 1.222 & & \\
Total & 868.960 & 12 & & & \\
Corrected Total & 238.210 & 11 & & & \\
\hline
\end{tabular}

Dari tabel 6, didapatkan nilai-nilai penting yang bisa disimpulkan sebagai berikut:

\section{Model yang dikoreksi (Corrected Model)}

Pengaruh semua variabel independen (faktor A, faktor B dan interaksi antara faktor A dengan faktor B) secara bersama-sama mempunyai pengaruh karena nilai signifikansinya 0,000 sehingga data diatas menunjukkan model valid (apabila signifikansi (Sig.) < 0,05 (Alfa) maka model koreksi signifikan).

Penyadapan (Intercept) 
Nilai perubahan variabel dependen tanpa perlu dipengaruhi keberadaan variabel independent. Dari data analisis diatas dapat dikatakan intercept signifikan karen menunjukkan nilai signifikansi $0,000(<0,05=$ signifikan $)$.

\section{Faktor A}

Pengaruh faktor A terhadap nilai $\mathrm{pH}$ dapat dikatakan signifikan apabila nilai signifikansi menunjukkan nilai $<0,05$. Dari data analisis tersebut menunjukkan nilai signifikansi 0,000 sehingga faktor A terhadap nilai $\mathrm{pH}$ berpengaruh secara signifikan.

\section{Faktor B}

Pengaruh faktor $\mathrm{B}$ terhadap nilai $\mathrm{pH}$ dikatakan signifikan apabila nilai signifikansi menunjukkan nilai $<0,05$. Dari data analisis diatas menunjukkan nilai signifikansi 0,724 sehingga faktor B terhadap nilai $\mathrm{pH}$ tidak berpengaruh secara signifikan $(>0,05=$ tidak berpengaruh).

\section{Faktor A* Faktor B}

Pengaruh faktor $\mathrm{A} *$ faktor B dikatakan signifikan apabila nilai signifikansi menunjukkan nilai $<0,05$. Dari data diatas menunjukkan bahwa pengaruh faktor $\mathrm{A} *$ faktor $\mathrm{B}$ adalah tidak berpengaruh secara signifikan dengan nilai signifikansi $0,350(>0,05=$ tidak berpengaruh $)$.

Hasil penelitian menunjukkan bahwa semakin besar konsentrasi pretreatment maka derajat keasaman dan kebasaan semakin meningkat. Hal ini dikarenakan semakin tinggi konsentrasi yang digunakan maka larutan akan semakin pekat.

Rerata $\mathrm{pH}$ pretreatment $\mathrm{HCl} 4 \%$ adalah $2.7 \pm 0.45$ sedangkan $\mathrm{HCl} 2 \%$ adalah $3.1 \pm 0.08$. Hal ini menunjukkan bahwa semakin besar konsentrasi asam maka akan semakin asam pula nilai pH-nya. Sejalan dengan penelitian Huda et al. tahun 2013 melaporkan bahwa nilai pH pada konsentrasi pelarut $4 \%$ berbeda nyata pelarut asam dengan konsentrasi 5\% dan 6\% [6]. Semakin tinggi konsentrasi pelarut asam yang digunakan maka gelatin yang dihasilkan derajat keasamannya mengalami peningkatan. Hal ini dikarenakan semakin tinggi konsentrasi yang digunakan maka asam akan semakin pekat dan juga asam yang terikat pada ossein akan semakin banyak.

Rerata $\mathrm{pH}$ untuk pretreatment $\mathrm{NaOH} 4 \%$ adalah $12.03 \pm 0.82$ sedangkan $\mathrm{NaOH} 2 \%$ adalah $11.17 \pm 1.54$. Berdasarkan penelitian Siregar et al. pada tahun 2015 menyatakan bahwa jenis pelarut memberikan pengaruh berbeda sangat nyata $(\mathrm{p}<0.01)$ terhadap nilai $\mathrm{pH}$. Semakin kuat jenis asam yang digunakan untuk proses curing maka nilai $\mathrm{pH}$ semakin rendah [11]. Larutan curing asam kuat mempunyai $\mathrm{pH}$ rendah dan untuk asam lemah mempunyai $\mathrm{pH}$ tinggi. Dengan kata lain apabila semakin kuat jenis basa maka nilai $\mathrm{pH}$ akan semakin tinggi.

Kolagen umunya larut pada kondisi asam dengan $\mathrm{pH}$ maksimum untuk melarutkan kolagen dari kulit adalah 2 dan untuk $\mathrm{pH}$ maksimum kilagen tulang adalah 5. Perbedaaan $\mathrm{pH}$ yang terjadi untuk melarutkan kolagen baik yang berasal dari tulang maupun dari kulit disebebkan oleh sifat molekul dan konformasi masing-masing kolagen yang berbeda. Kolagen yang berasal dari kulit memiliki jumlah iaktan silang yang lebih sedikit dibandingkan kolagen yang berasal dari tulang. Jumlah ikatan silang berpengaruh terhadap tingkat kelarutan kolagen, sehingga kolagen yang berasal dari tulang memiliki tingakat kelarutan lebih tinggi debandingkan dengan kolagen yang berasal dari kulit [1].

\section{Berat Kasar Kolagen}

Berat kasar kolagen diperoleh dari selisih antara berat awal kulit yang dikurangi dengan berat akhir kulit setelah diekstraksi.

Tabel 7. Pengaruh pretreatment terhadap berat kasar kolagen

\begin{tabular}{|c|c|c|c|c|}
\hline & & \multirow{2}{*}{ Ulangan } & \multicolumn{2}{|c|}{ Faktor B (Konsentrasi) } \\
\hline & & & $2 \%$ & $4 \%$ \\
\hline \multirow{6}{*}{$\begin{array}{c}\text { Faktor A } \\
\text { (Pretreatment) }\end{array}$} & & 1 & 15.3 & 21.73 \\
\hline & $\mathrm{HCl}$ & 2 & 14.64 & 19.67 \\
\hline & & 3 & 14.4 & 22.6 \\
\hline & \multicolumn{2}{|c|}{ Rata-rata } & $14.78 \pm 0.38$ & $21.33 \pm 1.22$ \\
\hline & \multirow{2}{*}{$\mathrm{NaOH}$} & 1 & 43.63 & 48.16 \\
\hline & & 2 & 43.3 & 48.8 \\
\hline
\end{tabular}




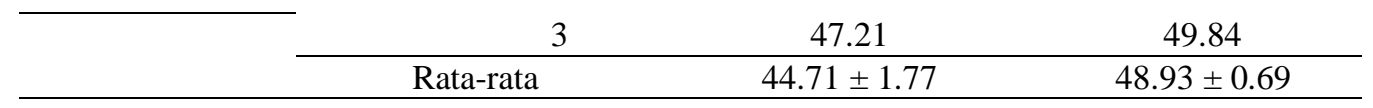

Tabel 8. Levene's Test of Equality of Error Variances dengan berat kasar kolagen sebagai variabel dependen.

\begin{tabular}{cccc}
\hline F & df1 & df2 & Sig. \\
\hline 3.453 & 3 & 8 & .071 \\
\hline
\end{tabular}

Keterangan : Pengujian hipotesis nol berdasarkan varian kesalahan pada variable dependen pada semua kelompok

Berdasarkan daftar sidik ragam pada tabel 8 menunjukkan bahwa nilai signifikansi 0,071. Sehingga dapat disimpulkan bahwa varian antar group berbeda secara signifikan dikarenakan nilai signifikansi menunjukkan nilai $>0,05$.

Tabel 9. Tests of Between-Subjects Effects dengan berat kasar kolagen sebagai variabel dependen

\begin{tabular}{cccccc}
\hline Source & $\begin{array}{c}\text { Type III Sum } \\
\text { of Squares }\end{array}$ & df & Mean Square & F & Sig. \\
\hline Corrected Model & $2573.695^{\mathrm{a}}$ & 3 & 857.898 & 434.236 & .000 \\
Intercept & 12628.243 & 1 & 12628.243 & 6391.944 & .000 \\
Faktor_A & 2482.563 & 1 & 2482.563 & 1256.581 & .000 \\
Faktor_B & 87.049 & 1 & 87.049 & 44.061 & .000 \\
Faktor_A $*$ & 4.083 & 1 & 4.083 & 2.067 & .188 \\
Faktor_B & 15.805 & 8 & 1.976 & & \\
Error & 15217.744 & 12 & & & \\
Total & 2589.500 & 11 & & & \\
Corrected Total &
\end{tabular}

Berdasarkan dari tabel Tabel 9, dapat disimpulkan sebagai berikut:

\section{Model yang dikoreksi (Corrected Model)}

Pengaruh semua variabel independen (faktor A, Faktor B dan interaksi faktor A dengan faktor B) secara bersama-sama mempunyai pengaruh karena nilai signifikansi 0,000 sehingga menunjukkan model valid.

\section{Penyadapan (Intercept)}

Nilai perubahan variabel dependen tanpa perlu dipengaruhi keberadaan variabel independen. Dari data analisis tersebut menunjukkan bahwa intercept signifikan dengan nilai $0,000(<0,05=$ signifikan $)$.

\section{Faktor A}

Pengaruh faktor A terhadap berat kasar kolagen dapat dikatakan signifikan apabila nilai signifikansi menunjukkan nilai $<0,05$. Dari data analisis diatas signifikansi menunjukkan nilai 0,000 sehingga faktor A terhadap berat kasar kolagen berpengaruh secara signifikan.

\section{Faktor B}

Pengaruh faktor B terhadap berat kasar kolagen dapat dikatakan signifikan apabila signifikansi menunjukkan nilai $<0,05$. Dari data analisis diatas signifikansi menunjukkan nilai 0,000 sehingga faktor B terhadap berat kasar kolagen berpengaruh secara signifikan.

\section{Faktor A * Faktor B}

Pengaruh faktor A * faktor B dikatakan signifikan apabila signifikansi menunjukkan nilai $<0,05$. Data analisis diatas menunjukkan bahwa pengaruh faktor $\mathrm{A} *$ faktor $\mathrm{B}$ adalah tidak berpengaruh secara signifikan dengan nilai signifikansi $0,188(>0,05=$ tidak berpengaruh).

Hasil pretreatment memberikan pengaruh berbeda secara signifikan terhadap berat kasar kolagen kulit kaki ayam berdasarkan tabel 8. Rerata berat kasar kolagen dapat dilihat pada tabel 7 yang menunjukkan rerata tertinggi untuk berat kasar kolagen adalah pada pretreatment $\mathrm{NaOH}$ 
$4 \%$ yaitu $48.93 \pm 0.69$. Sedangkan rerata berat kasar kolagen terendah adalah pada pretreatment $\mathrm{HCl} 2 \%$ yaitu $14.78 \pm 0.38$.

Berdasarkan data diatas menunjukkan bahwa konsentrasi berpengaruh terhadap berat kasar kolagen, semakin tinggi konsentrasi pretreatment maka berat kasar kolagen yang dihasilkan akan tinggi pula. Begitupun sebaliknya apabila konsentrasi pretreatment rendah maka berat kasar kolagen yang dihasilkan akan semakin rendah juga. Berat kasar kolagen diperoleh dari hasil selisih antara berat awal kulit dikurangi dengan berat akhir kulit setelah diekstraksi. Sehingga berat kasar kolagen berhubungan dengan proses curing dan ekstraksi.

Fase curing dilakukan dengan merendam bahan baku dalam kondisi tertentu dengan tujuan untuk mendenaturasi asam-asam amino penyusun molekul kolagen sehingga pada proses ekstraksi (hidrolisa) ikatan kimia yang terlipat dalam struktur protein kolagen akan mudah mengalami proses pelarutan [10]. Tujuan dari perendaman atau hidrolisis dalam asam dan basa adalah untuk melemahkan struktur kolagen, demineralisasi melarutkan sebagian dari ikatan peptida dengan masih mempertahankan konsistensi kolagen. Proses hidrolisis ini disebut juga sebagai proses denaturasi untuk mengubah serat kolagen yang tidak larut dalam air menjadi larut dalam air dan mudah dicerna. Ikatan yang mungkin terpecah dalam proses ini adalah ikatan gidrogen, interaksi hidrofobik, ikatan ionik dan ikatan Van der Waals yang terbentuk diantara rantai polipeptida. Terpecahnya ikatan inilah yang menyebabkan berubahnya sifat kelarutan kolagen terhadap air [8].

Ekstraksi merupakan proses pemisahan suatu bahan atau beberapa zat berdasarkan pada perbedaan sifat kelarutannya dalam suatu bahan pelarut. Beberapa faktor yang berpengaruh dalam proses ekstraksi adalah ukuran pertikel bahan ang akan diekstrak, bahan pelarut, suhu, waktu, $\mathrm{pH}$ dan metode yang digunakan. Ekstraksi kolagen biasanya dilakukan dengan menggunkaan iar sebagai bahan pelarut, kondisi netral, pada kisaran suhu $60-95^{\circ} \mathrm{C}$ selama beberapa waktu [1].

\section{KESIMPULAN}

Formula yang tepat dalam memproduksi kolagen kulit kaki ayam adalah menggunakan pretreatment $\mathrm{NaOH} 4 \%$ dan pretreatment $\mathrm{HCl} 4 \%$. Kualitas kolagen terbaik dihasilkan oleh pretreatment $\mathrm{NaOH} 4 \%$ dan pretreatment $\mathrm{HCl} 4 \%$.

\section{DAFTAR PUSTAKA}

[1]. Sugihartono, Erwanto, Y., dan Wahyuningsih, R., Kolagen dan gelatin untuk industri pangan dan kesehatan. 2019. Lily Publisher. Yogyakarta

[2]. Susanto, E., Peptida bioaktif sebagai antioksidan eksplorasi pada ceker ayam. 2019. Deepublisher (Grup Penerbit CV Budi Utama) . Yogyakarta

[3]. Peranginangin R, Rahmad W. Pengolahan Kolagen dari Kulit Ikan Nila. Penebar Swadaya Grup; 2006.

[4]. Rachmania, R., A., Nisma, F., dan Mayangsari, E., Ekstraksi gelatin dari tulang ikan tenggiri melalui proses hidrolisis menggunakan larutan basa. Media Farmasi, 2013. Vol. 10 No. $2: 18-28$

[5]. Putra AN, Sahubawa L, Ekantari N. Ekstraksi dan karakterisasi kolagen dari kulit ikan nila hitam (Oreochromis niloticus). Jurnal pascapanen dan bioteknologi kelautan dan perikanan. 2013 Dec 16;8(2):171-80.

[6]. Huda WN, Atmaka W, Nurhartadi E. Kajian karakteristik fisik dan kimia gelatin ekstrak tulang kaki ayam (Gallus gallus bankiva) dengan variasi lama perendaman dan konsentrasi asam. Jurnal Teknosains Pangan. 2013 Jul;2(3).

[7]. Hasdar, M., dan Randi, M., J., Comparative quality of proteins and morphological structures of gelatin from sheepskin with acid and alkaline treatment. Foodscitech, 2020. Vol. 3 No. 2

[8]. Siregar H, Ginting S, Limbong LN. Pengaruh jenis pelarut dan suhu ekstraksi kaki ayam terhadap karakteristik fisik dan kimia gelatin yang dihasilkan. Jurnal Rekayasa Pangan dan Pertanian. 2015;3(2):171-7. 
[9]. Indrawan MR, Agustina R, Rijai L. Ekstraksi Gelatin dari Kaki Ayam Broiler Melalui Berbagai Larutan Asam dan Basa dengan Variasi Lama Perendaman. Journal of Tropical Pharmacy and Chemistry. 2016 Dec 31;3(4):313-21.

[10]. Wijaya OA, Surti T, Sumardianto S. Pengaruh lama perendaman naoh pada proses penghilangan lemak terhadap kualitas gelatin tulang ikan nila (Oreochromis niloticus) (Doctoral dissertation, Diponegoro University).

[11]. Rahmawati R, Nurjanah S. Pengaruh Konsentrasi Enzim Papain Terhadap Mutu Gelatin Bubuk Dari Tulang Dan Cakar Ayam. Jurnal Konversi. 2020 Apr 20;9(1):14. 